SHS Web of Conferences 10, 00024 (2014)

DOI: $10.1051 /$ shsconf/20141000024

C Owned by the authors, published by EDP Sciences, 2014

\title{
Monetary and marital satisfaction as factors facilitating birth-rate in latvian families
}

\author{
S. Mihailova ${ }^{1}$ and I. Tretjakova ${ }^{2}$ \\ ${ }^{1}$ Rīga Stradinš̌ University, Latvia \\ ${ }^{2}$ Daugavpils University, Latvia
}

\begin{abstract}
The paper focuses on correlations between monetary and marital satisfaction and the number of children. A questionnaire specially elaborated by I. Tretjakova was applied to poll 221 respondents aged 20-40. The study results lead to the conclusion that monetary or marital satisfaction is an emotional state following from the realisation of a definite motive or fulfilment of expectations.

Real family income correlates with the number of children in the family, but subjective satisfaction does not correlate with the number of children in the family. Income determines relinquishment to procreate less than other factors.

Family income and satisfaction with them do not correlate with relationship satisfaction and relationship problems. Thus, there is no correlation between the number of children in the family and relationship and monetary satisfaction.
\end{abstract}

\section{Introduction}

During recent years, in a number of European countries including Latvia birth-rate has been decreasing (see Fig. 1). Thus, a demographic-economic paradox can be observed - birth-rate is decreasing exactly in the economically developed countries. Hence, the opinion that poor economic situation is a reason to relinquish procreation has not proved true. In the second part of the $20^{\text {th }}$ century, in developed countries, demographic modernisation has occurred, the main features of which were birth-rate decrease, increase of the number of induced abortions and increase of birth-rate in extramarital relations as well as liberalisation of marriage and family relations. (Goltsova E., V. \& Leshchenko, Ia.A., 2011).

Deviation of any system from an optimal dynamic balance (human birth-rate is decreasing - it is below the population regeneration level) is connected with interaction of several factors. Therefore, it is all the more important to study the possible mutually interrelated aspects of the low birth-rate in society - transformation of the family as a system of values, relationship issues, influence of the social environment, level of education, striving for one's career, number of abortions, the state of health etc.

Human ability to procreate and the topicality of the low birth-rate in the 21 st century is a phenomenon concerning which the answers shall be sought for without delay until it is too late. Solution of this issue is especially important for small nations including Latvians, otherwise Latvians can become extinct.

This is an Open Access article distributed under the terms of the Creative Commons Attribution License 4.0, which permits unrestricted use, distribution, and reproduction in any medium, provided the original work is properly cited. 


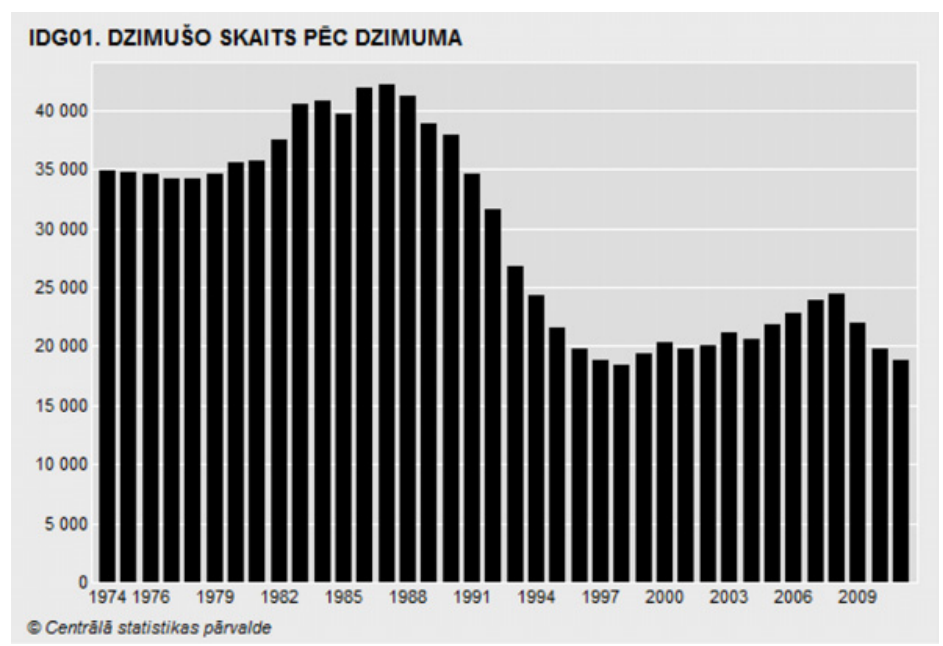

Figure 1. Data of the Central Statistics Bureau on the number of newborns from 1974 to 2011.

This paper represents part of a large study with the aim of ascertaining the possible reasons for the low birth-rate in Latvia, focusing not only on financial aspects but also on psychological ones. Thus, in this paper only a part of a 2012-2013 pilot study on birth-rate facilitating factors has been analysed. The goal of this particular study is to investigate correlations between family income, the number of children in the family and relationship quality (relationship satisfaction). In order to achieve the set goal, the following tasks were brought forward: to ascertain in what way the respondents' income are connected with their marital satisfaction; to study how income satisfaction and marital satisfaction is connected with the number of children.

When starting the pilot study, several hypotheses were brought forward: There is correlation between the number of children in the family and relationship satisfaction, and monetary satisfaction; family income and income satisfaction correlate with the number of children in the family; family income and income satisfaction correlate with relationship satisfaction and relationship problems; income correlates with factors that determine unwillingness to procreate aged 20-40 were surveyed (mean age 30.6) and 36 males (mean age 32.0).

In order to achieve the set goal and prove the hypotheses, by applying a specially elaborated questionnaire, 185 females.

\section{Theoretical justification: Monetary and marital satisfaction}

Satisfaction as general characteristics of a person's attitude towards the surrounding world and its objects and phenomena, in a complex and systemic way, characterises interaction "person - the surrounding world". In social studies satisfaction shows how successfully a person has adapted to particular circumstances. Traditionally material satisfaction is interpreted as monetary or financial satisfaction. Monetary satisfaction/dissatisfaction is an important indicator of social and psychological well-being (Семенов, 2011; 106). "Satisfaction is an emotional state emerging as a consequence of realisation of a motive. The majority of psychologists and sociologists interpret "satisfaction" as attitude towards the action to be performed, to one's way of life." (Ильин Е. П., 2000, с. 62). Thus, two forms of satisfaction can be distinguished: satisfaction as a process and satisfaction as a result, or contentment.

As indicated by an investigator of Russian monetary relations, J. Semenov (Семенов, 2011; 122), monetary satisfaction is determined by several factors: the size of real income and the level of personal 


\section{Int. Conf. SOCIETY. HEALTH. WELFARE.}

well-being, the power of monetary requirements compared to other needs, comparison of real and desirable financial well-being; personality orientation and some personal traits: optimism, motivation for achieving success, locus of control, stress level, self-assurance development level; respondents' attitude towards financial well-being; experience of satisfying monetary requirements in the past, and the possibility to achieve the desirable financial well-being level in the future.

The research literature on marital satisfaction is somewhat of a mess. Historically, this research has suffered from the use of ambiguous and overlapping terms. Over the years, researchers have used a variety of synonyms for marital satisfaction, including marital quality, marital success, adjustment, happiness, satisfaction, consensus, companionship, and integration. According to the literature, marital satisfaction is the subjective evaluation of one's experience in their marriage. Individuals are usually satisfied when their needs are being met, and when the individuals expectations and desires are being satisfied.

As indicated by Maija Biseniece, a psychologist and family therapist (Biseniece, 2014), relationship satisfaction of a couple is one of the most frequently studied topics in family psychology. Its importance in man's life is vitally significant (Markus \& Kitayama, 1991).

As one of criterions for relationship satisfaction, the motivation to maintain lengthy relationship is usually mentioned in cases when various resources (time, money etc.) have been invested. Studies led to the conclusion that among important resources for lengthy relationship of a couple, similitude of education level and religious views should be noted (Heaton, 2002; Asmari, Solberg \& Solon, 2008), satisfaction with intimate and sexual relationship (Field, 1988; Christopher \& Sprecher, 2000; Young, Denny, Young \& Luquis, 2000, as mentioned in Litzinger \& Gordon, 2005; Sprecher, 2002), common interests and their dominance over the individual ones, common positive memories and being together (Hill, Rubin \& Peplau, 1976; Holmer, 2004), time spent together, family and friends' support (Felmlee, Sprecher, \& Bassin, 1990).

Recent research studies (Shiota, Levenson, 2007¹ Султанова, 2008; Rosowsky, King, Coolidge, Rhoades, Camille, Segal, $2012^{2}$ a.o.) highlight that marital satisfaction and well-being are largely determined by personal traits of the spouses: for example, consistence of behaviour, harmony of characters, psychological maturity of partners. Sultanova found (Султанова, 2008; 22), that one of the most important features ensuring marital satisfaction is tolerance characterised by "internal locus of control", acceptance of oneself and others. Several Russian psychologists (Л.В. Куликов, В.М. Менделевич, В.А. Ананьев, А.Г. Асмолов, П. Куттер, А.В. Петровский, Б.Д. Парыгин, К. Муздыбаев, Е.Ю. Коржова, Г.В. Семенова, Султанова) emphasize the effect of responsibility of spouses on marital satisfaction and healthy moral-psychological atmosphere in the family.

For relationship satisfaction, mutual empathy of the couple is important (Biseniece, 2014) which is facilitated by openheartedness of the couple and sharing one's thoughts and feelings, thus, the relationships are unconstrained, calm and natural and there is no distinct division of power.

An important factor for marital satisfaction is also the partners' ability to overcome stress, both individually and together, effective adaptation tactics and choice of coping-strategies in stress situations and in family interaction. Couples who are capable for more successful social-psychological adaptation in the existing situation, reach a higher-level well-being than those who cannot. (Султанова, $2008 ; 16)$.

Recent research studies emphasize that the quality of marital or extramarital relations is largely affected by the ability of the partners to forgive (McCullough,1998, Hill, 2001; Fincham, 2004;

\footnotetext{
${ }^{1}$ Shiota M., Levenson R. Birds of a Feather Don't Always Fly Farthest: Similarity in Big Five Personality Predicts More Negative Marital Satisfaction Trajectories in Long-Term Marriages // Psychology and Aging, Dec.2007, Vol 22, Issue 4, p.666-675.

${ }^{2}$ Rosowsky E., King K., Coolidge F., Rhoades C., Segal D. Marital Satisfaction and Personality Traits in Long-Term Marriages: An Exploration Study. // Clinical Gerontologist Mar/Apr 2012, Vol 35., Issue 2, p.77-78.
} 


\section{SHS Web of Conferences}

Allemand et al., 2007), ability to communicate and provide mutual emotional support (Litzinger \& Gordon, 2005; Cramer, 2003), ability to adjust to one another and make a compromise (Belanger, Sabourin \& El-Baalbaki, 2012). Exactly the ability to forgive ensures constructive conflict resolution among partners, improves relationship and prevents new conflicts before they have broken out (Worthington \& DiBlasio, 1990, as mentioned in Kachadourian et al., 2004), and this positively affects general relationship satisfaction (McCullough, \& Worthington, Rachal, 1997). Easier conflict resolution is ensured by similarity of communication styles (Skinner \& Iaboni, 2009). A common feature for couples who are satisfied with their marriage is the fact that their relationship make less emphasis on daily routine problems but highlight the ability for mutual understanding, care and love for the partner (Hill, Rubin \& Peplau, 1976; Holmer, 2004; Султанова, 2008), and trust (Knox, Gibson, Zusman, \& Gallmeier, 1997), (24).

Partners are more satisfied with the couple's relations in case they enjoy mutual cooperation in child upbringing and consistent behaviour in relation towards the child, while mutual conflicts of partners concerning child upbringing issues decrease the couple's relationship satisfaction considerably (Pedro, Ribeiro \& Shelton, 2012). Marital satisfaction is affected also by the quality of relations with the spouses' parents (Султанова, 2008; 25).

Irrespective of the level of marital well-being, women more frequently than men feel dissatisfied with their marriage, which testifies that men are more satisfied with their marital relations than women. (Султанова, 2008; 16).

In case the sense of resentment accumulates, relationship satisfaction decreases rapidly for the partners, which can even bring to divorce (Coleman, 1998, as mentioned in Hill, 2001). Family therapists Eidemiller and Justickis (Эйдемиллер, Юстицкис, 2008; 53) found that dissatisfaction springs up when there is a huge contradiction between the real life in the relations between partners and expectations, which results in a frustrated emotional state. Manifestation of this dissatisfaction depends on the level of its acknowledgement.

\section{Materials and methods}

\section{Research methods}

In this study a specially elaborated questionnaire by I. Tretjakova was applied, the questions were created basing on the performed studies on low birth-rate in Europe and world at large as well as on the pilot survey having been carried out before the basic survey. It consisted of two parts: (1) socialdemographic and economic indicators including questions about respondents' age, family status, life environment, education, economic situation, number of children in the family; and (2) the contents part including questions on relations between partners, children, health and pregnancy, parent/children relations, values, factors affecting willingness or unwillingness to procreate. In total the questionnaire included 28 questions. However, within the frame of this paper only part of the questions will be analysed.

\section{Study procedure}

This pilot study was made as e-mediation since it was necessary only to gain insight in certain regularities. The respondents answered the questions without being in contract with the investigator. The survey questions were sent out electronically - by e-mail and also placed on social networks where the communication takes on in Latvian. Alongside the questionnaire also a cover letter was sent describing the goal of the survey and research ethics - ensuring of anonymity and confidentiality.

In order to ascertain the mean family income per month, several variants of reply were offered of which respondents checked the most appropriate one. In order to evaluate respondent's income 


\section{Int. Conf. SOCIETY. HEALTH. WELFARE.}

satisfaction (likewise as in the "Study of Factors Facilitating Marriage, Birth-rate and Positive Children/Parent Relationships" in 2004) a question was put: "In what way would you estimate the material situation of your family?", providing several variants of reply. Thus, in this study the subjective evaluation of one's economic state was used, basing on the methods elaborated by S. Ringen (1997) which has been applied in Latvia before in several studies (e.g., Sebre, Ïebedeva, Trapenciere, 2004).

In order to ascertain marital (relationship) satisfaction, a table containing the most important criteria characterising marriage was elaborated. Respondents had to check the most appropriate reply. Factors affecting the choice to procreate or to relinquish it were studied separately. Basing on the obtained data, interconnections were sought between monetary satisfaction, marital satisfaction and the choice, or relinquishment, to procreate.

\section{Statistical data analysis}

All study data have been processed using the statistical data analysis programme SPSS ("Statistical Program for the Social Sciences"). Data were mathematically summarised and statistically compared using Pearson and Spearmen correlation analysis, dispersion analysis, T-test criterion analysis.

\section{Study participants}

In total, 185 females participated in the study (mean age 30.6) and 36 males (mean age 32.0) aged 20-40 $(\mathrm{N}=221)$ of which $59 \%$ had children ( $42 \%$ - one child, $40 \%$ - 2 children, $18 \%-3$ children), but $41 \%$ were childless. Each respondent represented his/her family. Of those living in extramarital relationships, $17 \%$ had children, $83 \%$ were childless but of those who were married $-85 \%$ had children but $15 \%$ were childless, while of the divorced ones, $82 \%$ had children and $18 \%$ were childless.

Current satisfaction of respondents with their economic situation: $26 \%$ - satisfied, $44 \%$ - partly satisfied, $4 \%$ - very dissatisfied, $23 \%$ - dissatisfied, $3 \%$ - fully satisfied.

\section{Results}

\section{Family income - number of children}

In order to achieve the study goal, initially correlations were sought between real family income per family member and the real number of children in the family. Figure 2 shows that in case of one child, most frequently the income is Ls 300-500 a month per family member; in case of two children - most frequently, Ls 200-300 per family member, or Ls 500 and more; while in large families (three and more children) in $90 \%$ of the surveyed families there are only Ls 100-200 per family member and in $\sim 10 \%$ there is Ls 500 and more. Taking into consideration that the earners are most often only parents, then the more are family members, the less is the sum of money per family member. However, an interesting tendency can be observed that in families where the total income is over Ls 1000, parents most often choose to have two children instead of one. Correlations between the number of children and income level show that the number of children statistically significantly differ among various income groups (according to Anova test $F=11.031$, sig $=0.000$ ), and this is medium-high correlation (according to Spearman's correlation analysis).

Before creating the questionnaire, 100 persons of various age groups were polled about the reasons for unwillingness to procreate. Eight major factors were distinguished: new financial expenses; changing of way of life; not being able to pay enough attention to myself; fear to lose career / professional skills; fear from labour; fear to remain alone with the child; fear to lose physical attractiveness; unwillingness to take responsibility for the child - which were then included in the questionnaire. When filling in the questionnaire, respondents had to organise all the mentioned factors affecting the decision not to have 
SHS Web of Conferences

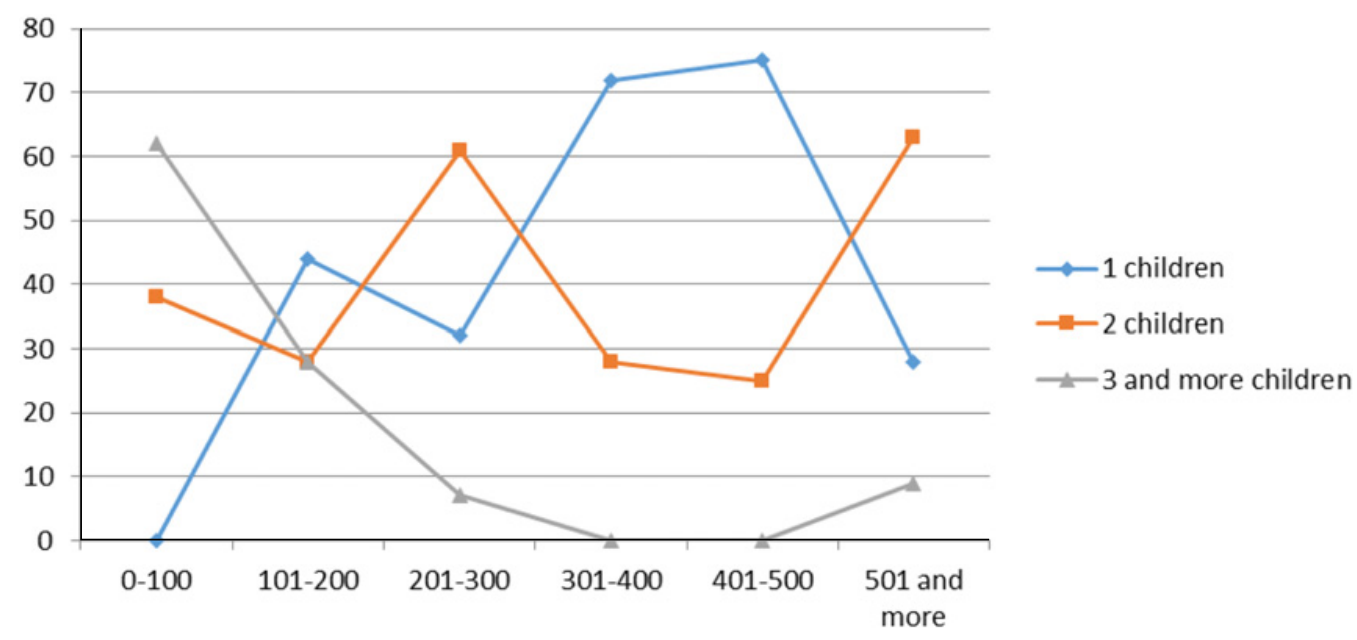

Figure 2. Number of children (\%) and average monthly income level per one person.

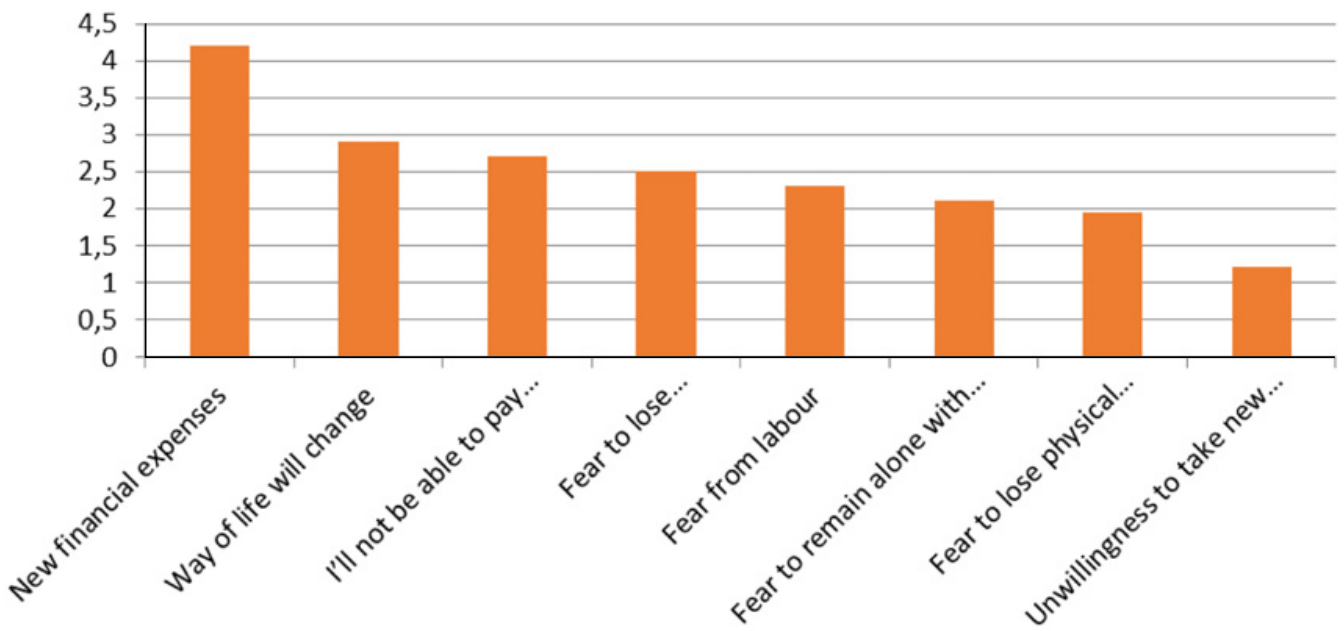

Figure 3. Factors affecting unwillingness to procreate (the shorter is the bar, the more important is the factor).

children in the family according to the level of significance. The results of the survey showed (see Fig. 3) that the reason of "new financial expenses" is an almost half-less important factor than others.

Thus, family income is an essential factor affecting the choice to procreate and the number of children in the family, but the amount of income is an insignificant factor for the decision not to procreate. However, it is to be emphasised that the results of this survey show only the conscious choice while the unconscious one remains unknown. As indicated by Sandra Jirgena in her doctoral thesis (Jirgena, 1999), any choice is affected by a an aggregate of a number of factors: a person makes choices in order to gain satisfaction, facilitate self-development and realise his/her opportunities; reach stability and identity and neutralise one's inner conflicts; find the cause and essence of one's existence; reach one's unconscious goals, make successful interaction with the surrounding world and influence it; reach projected results and satisfy one's needs. Thus, in order to understand people's motivation to procreate, or not to procreate, it is essential to investigate also the unconscious motives. 
Int. Conf. SOCIETY. HEALTH. WELFARE.

Table 1. Questions characterising marital satisfaction and replies (\%).

\begin{tabular}{|l|l|l|l|l|l|}
\hline & $\begin{array}{l}\text { All the } \\
\text { time }\end{array}$ & $\begin{array}{l}\text { More } \\
\text { frequently }\end{array}$ & Sometimes & Seldom & Never \\
\hline Feel safe in relations with the partner & $38.7 \%$ & $45.9 \%$ & $10.8 \%$ & $3.2 \%$ & $1.4 \%$ \\
\hline Mutual respect & $44.1 \%$ & $48.2 \%$ & $5.4 \%$ & $1.4 \%$ & $.9 \%$ \\
\hline $\begin{array}{l}\text { Share emotional experiences, thoughts } \\
\text { opinions, joys }\end{array}$ & $41.9 \%$ & $40.5 \%$ & $14.4 \%$ & $2.3 \%$ & $.9 \%$ \\
\hline $\begin{array}{l}\text { Ability to peacefully discuss cohabitation } \\
\text { or conjugal life issues }\end{array}$ & $28.5 \%$ & $45.2 \%$ & $20.4 \%$ & $4.1 \%$ & $1.8 \%$ \\
\hline Relationship is characterised by conflicts & & $7.0 \%$ & $33.0 \%$ & $53.0 \%$ & $7.0 \%$ \\
\hline Feeling of emotional comfort in relationship & $20.5 \%$ & $54.3 \%$ & $14.6 \%$ & $7.3 \%$ & $3.2 \%$ \\
\hline $\begin{array}{l}\text { Feeling of emotional isolation and } \\
\text { loneliness in relationship }\end{array}$ & $1.4 \%$ & $4.5 \%$ & $20.5 \%$ & $44.5 \%$ & $29.1 \%$ \\
\hline Satisfied with relations with the partner & $27.3 \%$ & $55.9 \%$ & $8.2 \%$ & $5.9 \%$ & $2.7 \%$ \\
\hline
\end{tabular}

\section{Most important factors}

As follows from Figure 3, the most important factor (the lowest bar) affecting unwillingness to procreate is "unwillingness to take new responsibility" while the least essential one is "new financial expenses".

Correlations between family income and the importance of factors affecting the decision not to have children in the family show that there are no statistically significant differences between various income groups concerning the importance of the studied negative factors. Of these factors, only "inability to pay enough attention to oneself" and "unwillingness to take new responsibility" are slightly positively connected with the level of income. Family income has no statistically significant correlation with other factors, which means that the importance of factors affecting unwillingness to procreate is not affected by the family income level.

Summarising the obtained data, the conclusion is that the economic condition is an inessential factor affecting unwillingness to procreate.

Similar results were obtained in a 2004 study (Sebre S., Lsebedeva L., Trapenciere I., 2004) when, investigating whether there exists a close correlation between the economic condition of the family and the planned and optimal number of children in the family, it was found that there is no correlation between family's self-evaluation of its economic condition and neither the planned, nor the optimal number of children in the family. In this study a probability was expressed: it is most feasible that smaller income does not stimulate the willingness to have a larger family, but sooner, children's current needs determine the shortage of this material basis. However, the study data did not show that the economic condition of the family as evaluated by respondents is the main facilitating or impeding reason for willingness to have a larger family, but sooner, that considerations about the planned and optimal size of the family are associated with various opinions and values.

\section{Family income - marital satisfaction}

Before creating the questionnaire, 100 persons of various age groups were polled about the factors affecting relations with the partner. Basing on the data obtained in this survey several factors of relationships were distinguished: safety, trust, respect, sharing with the other one, ability to communicate, conflict making, emotional comfort / discomfort, relationship satisfaction and several relationship problems: emotional / physical violence, alcohol / drug abuse and computer addiction that were included in the questionnaire of the pilot study. The results obtained for each of the factors will be discussed below (see Table 1). 
SHS Web of Conferences

Table 2. Relationship problems and their frequency in families (\%).

\begin{tabular}{|l|l|l|l|l|l|}
\hline $\begin{array}{l}\text { Problems in our relationships } \\
\text { are created by: }\end{array}$ & $\begin{array}{l}\text { All the } \\
\text { time }\end{array}$ & Often & Sometimes & Seldom & Never \\
\hline Emotional violence & $1.4 \%$ & $5.4 \%$ & $16.7 \%$ & $22.5 \%$ & $54.1 \%$ \\
\hline Physical violence & & $0.5 \%$ & $1.4 \%$ & $5.0 \%$ & $93.2 \%$ \\
\hline Alcohol addiction & $1.4 \%$ & $4.1 \%$ & $5.9 \%$ & $15.8 \%$ & $72.9 \%$ \\
\hline Drug addiction & & $0.9 \%$ & $0.5 \%$ & $2.7 \%$ & $95.9 \%$ \\
\hline Computer addiction & $1.8 \%$ & $5.0 \%$ & $14.1 \%$ & $23.6 \%$ & $55.5 \%$ \\
\hline
\end{tabular}

The table shows that most of the respondents check feeling safe, emotional comfort in relations, partners feel respect for each other, share experiences, and conflicts are rare in respondents' families, they seldom feel emotional isolation, therefore, $83 \%$ of respondents are satisfied with their relationships. Thus, the conclusion can be made that in this study the respondents are represented by members of favourable families, or that people have not been frank enough when filling in the questionnaires, and have checked socially beneficial replies. Most seldom the respondents feel emotional isolation and loneliness in their families.

Further various popular relationship problems will be discussed. Table 2 shows that most frequently there is emotional violence in respondents' families and mostly computer and alcohol addition have been mentioned. However, this respondent group is dominated by representatives of families in which the mentioned relationship problems are rare.

Least of all the respondents are affected by the following problems - physical violence and drug addiction.

Correlations between family income and marital satisfaction show that there are no statistically significant differences between various income groups, in no aspects of the studied relations between partners, and not any of the studied aspects of relations is statistically significantly correlated with the income level, and also none of the studied relationship problems is statistically significantly correlated with the income level.

Thus, it follows that family income and monetary satisfaction are not related with relationship satisfaction and relationship problems. It is to be taken into consideration that all respondents were employed, and therefore, this tendency can be attributed only to families having income. Possibly, in families who subsist only on social benefits the correlations are different. Also, it is to be noted that among these respondents there was no one with income over Ls. 1000 per family member, and thus all the achieved results apply only to middle-class families.

\section{Relations with the partner and the number of children in the family}

Correlations between the number of children and marital satisfaction show that there are no statistically significant differences between various numbers of children in a family in no aspect of the studied relations between partners, and not any studied aspects of relations is statistically significantly correlated with the number of children, as well as none of the studied relationship problems is statistically significantly correlated with the number of children.

\section{Discussion and conclusions}

- Monetary or marital satisfaction is an emotional state springing up as a consequence to realisation of a definite motive, or fulfilment of expectation;

- Real family income correlates with the number of children in the family, but subjective satisfaction does not correlate with the number of children in the family, thus, the hypothesis "family income 


\section{Int. Conf. SOCIETY. HEALTH. WELFARE.}

and income satisfaction correlate with the number of children in the family" prove true only partly. Income determines relinquishment to procreate less than other factors.

- The hypotheses "family income and satisfaction with them correlate with relationship satisfaction and relationship problems" and "income correlates with factors determining unwillingness to procreate" do not prove true.

- The hypothesis "There is correlation between the number of children in the family and relationship and monetary satisfaction" does not prove true.

In order to gain a more complete picture of the issue under study, it would be essential to investigate not only the conscious but also the unconscious factors affecting the choice to procreate. This study focused on issues demanding in-depth investigation. The results obtained do not characterise the situation in Latvia at large, since the choice of respondents was not large, and cannot be attributed to the total cluster. Among the respondents, there were no unemployed persons. Also, it should be noted that among the respondents there was no one having income over Ls 1000 per family member, thus, all the obtained results apply only to families with medium income. Since this was a pilot study, no regularities can be found, but instead, only tendencies. Whether they can be confirmed in a larger study group - this is a task for future research.

\section{References}

[1] Berga, G., Tiltiņa, I., Buša, I., Dūšelis, S., (2005) Laulību šķiršanas, laulību noturības un dzimstības veicinošo faktoru izpēte. http://www.lm.gov.lv/upload/berns_gimene/bernu_ tiesibas/petijums_lauiliba.pdf

[2] Goltsova E., Leshchenko A. (2011) Factors of the Social Environment as Determinants of Marriage and Birthrates. Sociological Researc., 50(6), 51-60.

[3] Jirgena S. (2006) Jauniešu pašizjūta un adiktīvas uzvedības izvēle. Rīga: Drukātava

[4] Lim, J. W. (2011). The changing trends in live birth statistics in Korea, 1970 to 2010. Korean Journal Of Pediatrics. 54 (11), 429-435

[5] Mills M., Rindfuss R. R., McDonald P., Te Velde, E. (2011) ESHERE reproduction and Society Task Force. Why do people postpone parenthood? Reasons and social policy incentives. Journal of Human reproduction Update. 17(6), 848-860

[6] Rosowsky E., King K., Coolidge F., Rhoades C., Segal D. (2012) Marital Satisfaction and Personality Traits in Long-Term Marriages: An Exploration Study. Clinical Gerontologist, 35(2), 77-78

[7] Sebre S., Ļebedeva L., Trapenciere I. (2004) Laulību, dzimstības un pozitīvu bērnu un vecāku attiecību veicinošo faktoru izpēte. Bērnu un gímenes lietu sekretariāts, Centrs pret vardarbību "Dardedze"

[8] Shiota M., Levenson R. (2007) Birds of a Feather Don’t Always Fly Farthest: Similarity in Big Five Personality Predicts More Negative Marital Satisfaction Trajectories in Long-Term Marriages. Psychology and Aging. 22(4), 666-675

[9] Shmidt, L., Sobotka, T., Bentzen, J.G., Andersen, A. (2011). Demographic and medical consequences of the postponement of parenthood. ESHRE Reproduction and Society Task Force. Oxford: Journal of Human reproduction Update. 18(1), 29-43

[10] Snyder D.K. (1979) Multidimensional assessment of marital satisfaction. Journal of Marriage and Family, 41, 813

[11] Te Velde E., Habbema, D., Leridon, H., Eijkemans, M. (2012) The effect of postponement of first motherhood on permanent involuntary childlessness and total fertility rate in six European countries since the 1970s. Oxford: Journal of Human reproduction. 27(4), 1179-1183 
SHS Web of Conferences

[12] Zamotkina J., Žarkovs, V. (2011) Faktori, kas ietekmē dzimstību Latvijā, Eiropā un pasaulē. Doctus. // http://www.doctus.lv/2011/2/faktori-kas-ietekme-dzimstibu-latvija-eiropa-un-pasaule

[13] Султанова А. (2008) Социально-психологические особенности супружеской совместимости и благополучия в брачных отношениях. Автореферат. СанктПетербургский государственный университет.

[14] Эйдемиллер Э., Юстицкис В. (2008) Психология и психотерапия семьи.- Санкт Петербург: Питер

[15] LR Centrālās statistikas pārvaldes mājas lapa // http://www.csb.gov.lv

[16] Marital satisfaction. http://www.toddkshackelford.com/downloads/Stone-Shackelford-ESP2007.pdf; http://www.springerreference.com/docs/html/chapterdbid/61476.html 